Banco, Volume 1, Mei 2019

\title{
RESPON PEGAWAI IAIN PAREPARE TERHADAP PRODUK PEMBIAYAAN BANK SYARIAH
}

\author{
Fadhliyah Ulfah Rustan \\ IAIN Parepare \\ fadliyahulfahrustan@gmail.com \\ Sitti Jamilah Amin \\ IAIN Parepare \\ sittijamilah@iainpare.ac.id \\ Syahriyah Semaun \\ IAIN Parepare \\ syahriyahsemaun@iainpare.ac.id
}

\begin{abstract}
Response is interpreted as a response, reaction and answer. A response will appear from receiving the message after a series of communications. Financing is one of the bank's main tasks, namely the provision of funds provision facilities to meet the needs of the parties which constitute a unit deficit. Employee response is used in this case to find out how much employees respond well or are interested in financing Islamic banks. This research is descriptive qualitative using a phenomenology approach. Therefore, the authors chose to use qualitative research methods to determine how to search, collect, manage, analyze data from research results and draw conclusions. The results of the study show that: 1) The financing system on Islamic bank products uses four different patterns or systems, namely: profit sharing system, buying and selling system, rental system, loan system. 2) Facilitie s provided by Islamic banks in the form of providing funds to meet the needs of parties with a profit sharing system. 3) Respondents' responses indicate that most respondents gave positive responses. This condition gives the impression that the employee's response to Islamic banking is perceived positively by respondents. Of the various types of products in Islamic banks, only the savings that are most sought after by sharia bank customers and
\end{abstract}




\section{Fadhliyah Ulfah Rustan, Sitti Jamilah, dan Syahriyah Semaun}

their reasons for choosing these products because of sharia-compliant, lawful and safe Islamic bank products.

\section{Keywords: Response, Islamic Bank, Financing}

\section{Abstrak}

Respon diartikan sebagai tanggapan, reaksi dan jawaban. Respon akan muncul dari penerimaan pesan setelah terjadinya serangkaian komunikasi. Pembiayaan merupakan salah satu tugas pokok bank, yaitu pemberian fasilitas penyediaan dana untuk memenuhi kebutuhan pihak-pihak yang merupakan defisit unit. Respon pegawai digunakan dalam hal ini untuk mengetahui seberapa besar pegawai yang merespon baik atau tertarik dalam hal pembiayaan pada bank syariah. Penelitian ini merupakan deskriptif kualitatif dengan menggunakan pendekatan fenomenologi. Oleh karena itu, penulis memilih menggunakan metode penelitian kualitatif untuk menentukan cara mencari, mengumpulkan, mengelola, menganalisis data hasil penelitian dan penarikan kesimpulan.Hasil penelitian menunjukkan bahwa: 1) Sistem pembiayaan pada produk bank syariah menggunakan empat pola atau sistem yang berbeda, yaitu : sistem bagi hasil, sistem jual beli, sistem sewa, sistem pinjaman. 2) Fasilitas yang diberikan oleh bank syariah berupa penyediaan dana untuk memenuhi kebutuhan pihak-pihak dengan sistem bagi hasil. 3) Tanggapan responden menunjukkan bahwa sebagian besar responden memberikan tanggapan positif. Kondisi ini memberikan kesan bahwa respon pegawai mengenai perbankan syariah dipersepsikan secara positif oleh responden.Dari berbagai jenis produk yang ada di bank syariah hanya tabungan yang paling banyak diminati nasabah bank syariah serta alasan mereka memilih produk tersebut karena produk bank syariah sesuai syariah, halal dan aman.

\section{Kata Kunci: Respon, Bank Syariah, Pembiayaan}

\section{A. Pendahuluan}

Lalu lintas Lembaga keuangan perbankan memiliki fungsi yang penting dalam perekonomian suatu negara. Fungsi tersebut adalah fungsi intermediasi keuangan, artinya bank sebagai lembaga perantara dalam penghimpunan dana masyarakat dalam bentuk simpanan dan penyaluran dana ke masyarakat dalam bentuk pinjaman atau kredit. ${ }^{1}$

Seiring berjalannya waktu banyak lembaga-lembaga yang memberikan kredit, termasuk bank-bank syariah di Indonesia.Bukan hanya kredit yang bank syariah salurkan tetapi ada juga pinjaman ringan untuk para konsumen yang memerlukan uang.Konsumen atau nasabah yang meminjam tentunya harus memenuhi beberapa syarat tertentu.Meskipun kredit syariah ini sudah dipasarkan ternyata banyak juga dari nasabah yang tidak mengetahui kredit syariah ini dan hanya sebagian dari nasabah yang mau memilih untuk menggunakan fasilitas pembiayaan pada bank syariah. Melihat masalah yang terjadi di atas setelah produk kredit

\footnotetext{
1 Zubair Hasan, Undang-undang Tentang Perbankan Syari'ah, (Jakarta: Rajagrafindo Persada, 2009),
} 
syariah dipasarkan maka dalam judul laporan ini adalah bagaimana pendapat atau respon pegawai IAIN Parepare terhadap produk pembiayaan pada bank syariah.

Pembiayaan merupakan salah satu tugas pokok bank, yaitu pemberian fasilitas penyediaan dana untuk memenuhi kebutuhan pihak-pihak yang merupakan defisit unit. Menurut sifat penggunaannya, (1) Pembiayaan produktif, yaitu pembiayaan yang ditujukan untuk memenuhi kebutuhan produksi dalam arti luas, yaitu untuk peningkatan usaha, baik usaha produksi, perdagangan, maupun investasi. (2) Pembiayaan konsumtif, yaitu pembiayaan yang digunakan untuk memenuhi kebutuhan konsumsi, yang akan habis digunakan untuk memenuhi kebutuhan. Menurut keperluannya, pembiayaan produktif dapat dibagi menjadi dua hal berikut. Pembiayaan modal kerja, yaitu pembiayaan untuk memenuhi kebutuhan: (a) peningkatan produksi, baik secara kuantitatif, yaitu jumlah hasil produksi, maupun secara kualitatif, yaitu peningkatan kualitas atau mutu hasil produksi; dan (b) untuk keperluan perdagangan atau peningkatan utility of place dari suatu barang. ${ }^{2}$

Keberadaan lembaga keuangan yang menawarkan berbagai bentuk fasilitas pembiayaan untuk lebih memperluas penyediaan pembiayaan alternatif bagi dunia usaha dalam sistem perekonomian modern sangatlah dibutuhkan.Lembaga pembiayaan diperlukan guna mendukukung dan memperkuat sistem keuangan nasional yang terdiversifikasi sehingga dapat memberikan alternative yang lebih banyak bagi pengembangan sektor usaha.

Ketentuan lebih lanjut ada dua kegiatan yang dikeluarkan dari kegiatan perusahaan pembiayaan, yaitu kegiatan perdagangan surat berharga berdasarkan Keputusan Menteri keuangan No. 1256/KMK.00/1989 tanggal 18 November 1989 karena kegiatan perdagangan surat berharga terkait dengan kegiatan di pasar modal. Selanjutnya modal ventura berdasarkan keputusan menteri keuangan No. 468/KMK.017/1995 tanggal 3 Oktober 1995 juga dikeluarkan dari bidang usaha lembaga pembiayaan dan dilakukan secara terpisah dengan badan hukum tersendiri dengan pertimbangan agar bisnis modal ventura dapat lebih berkembang dan berkonsentrasi pada penyaluran pembiayaan untuk membantu usaha kecil menengah.

Perkembangan selanjutnya, landasan hukum perusahaan pembiayaan makin kuat dengan Keputusan Menteri Keuangan RI No. 448/KMK-017/2000 yang diubah dengan Keputusan Menteri Keuangan No. 172/KMK.06/2002.Belakangan diterbitkan pula Peraturan Menteri Keuangan Nomor 84/PMK.012/2006 tentang Perusahaan Pembiayaan.

Perusahaan pembiayaan adalah badan usaha di luar bank dan lembaga keuangan bukan bank yang khusus didirikan untuk melakukan kegiatan yang termasuk dalam bidang usaha

\footnotetext{
${ }^{2}$ Muhammad Syafi' Antonio, Bank Syariab: Dari Teori Ke Praktik, Jakarta: Gema Insani Press, 2001), h. 160.
} 


\section{Fadhliyah Ulfah Rustan, Sitti Jamilah, dan Syahriyah Semaun}

lembaga Pembiayaan. ${ }^{3}$ Kegiatan usaha lembaga pembiayaan adalah: Sewa guna usaha atau leasing, anjak piutang atau factoring, usaha kartu kredit atau credit card, dan pembiayaan konsumen (consumer finance).Perusahaan pembiayaan selain beroperasi menggunakan sistem konvensional juga dapat melakukan pembiayaan berdasarkan prinsip syariah. Pembiayaan berdasarkan prinsip syariah adalah pembiayaan berdasarkan persetujuan atau kesepakatan antara perusahaan pembiayaan dengan pihak lain yang mewajibkan pihak yang dibiayai untuk mengembalikan pembiayaan tersebut dalam jangka waktu tertentu dengan imbalan ata bagi hasil. ${ }^{4}$

Bank sebagai lembaga intermediasi antara pihak surplus dengan pihak deposit mempunyai sedikitnya dua fungsi, yaitu: pengumpulan dana dan penyaluran dana. Penyaluran dana yang terdapat di bank konvensional dengan yang terdapat di bank syariah mempunyai perbedaan yang esensial, baik dalam hal nama, akad, maupun transaksinya. Dalam perbankan konvensional penyaluran dana ini dikenal dengan nama kredit sedangkan diperbankan syariah adalah pembiayaan.

Berbeda dengan pengertian kredit yang mengharuskan debitur mengembalikan pinjaman dengan pemberian bunga kepada bank, maka pembiayaan berdasarkan prinsip syariah pengembalian pinjaman dengan bagi hasil berdasarkan kesepakatan antara bank dan debitur.Pembiayaan merupakan aktivitas yang sangat penting karena dengan pembiayaan akan diperoleh sumber pendapatan utama dan penunjang kelangsungan usaha bank. Sebaliknya, bila pengelolaannya tidak baik akan menimbulkan permasalahan dan berhentinya usaha bank.

Keberhasilan sistem dalam produk pembiayaan hingga sekarang ini karena didukung oleh kualitas dan pelayanan yang diberikan oleh perusahaan tersebut.Oleh sebab itu faktorfaktor pengambilan keputusan dari calon nasabah dalam menggunakan pembiayaan pada bank syariah sangat penting diperhatikan demi kelangsungan dan tetap eksisnya suatu lembaga tersebut. Suatu lembaga dipandang mempunyai reputasi apabila lembaga itu diakui atau dipercaya sebagai perusahaan jasa dan nama baiknya di mata masyarakat. ${ }^{5}$

Namun berbeda dengan respon yang tergambar oleh salah satu pegawai IAIN Parepare bahwa kebutuhan pegawai akan sebuah produk pembiayaan pada bank syariah, tidak menarik dikarenakan pada produk bank syariah itu sama dengan poduk di bank konvensional, yang

\footnotetext{
${ }^{3}$ Keputusan Menteri Keuangan Nomor: 448/KMK.017/2000 tentang Perusahaan Pembiayaan yang diubah dengan Keputusan Menteri Keuangan No. 172/KMK.06/2002, dan PMK No.84/PMK.012/2006 tentang Perusahaan Pembiayaan. Diakses pada tanggal 13 nopember 2017.

4 DSN-MUI melalui surat Nomor: B-323/DSNMUI/XI/2007 tanggal 29 November 2007. Diakses pada tanggal 13 nopember 2017.

${ }^{5}$ Munawarotul Kiptiah, Respon kognitif, efektif dan konatifpegawai http:/ / repository.uinjkt.ac.id (Akses 21/02/2018 10.41 am).
} 
membedakan hanya ada pada nama produknya saja. Perguruan tinggi IAIN Parepare merupakan salah satu dari sekian banyaknya perguruan tinggi Islam di Indonesia, dan di dalam perguruan tinggi Islam tersebut terdapat sekian banyak umat Islam, mulai dari dosen, mahasiswa, pegawai, office boy/girl, bahkan sampai penjaga keamanan atau satpam. Mereka tersebut merupakan sasaran sosialisasi yang cukup besar bagi pembiayaan syariah, dalam usahanya menggaet nasabah guna meningkatkan kualitas perbankan syariah.

Melihat pembiayaan pada bank syariah dan beberapa perusahaan pembiayaan maka muncul masalah yang akan dibahas dalam penelitian ini yaitu bagaimana sistem pembiayaan pada bank syariah, bagaimana manfaat dari pembiayaan pada bank syariah dan bagaimana respon mengenai pembiayaan pada bank syariah. Salah satu hal menarik dari permasalahan ini dengan mengkhususkan pada pegawai yang berada di IAIN Parepare.

\section{B. Diskusi dan Pembahasan}

\section{Sistem Pembiayaan Pada Produk Bank Syariah}

Perbankan syariah adalah suatu sistem yang pelaksanaannya berdasarkan hukum Islam (syariah). Dalam pembentukan sistem diperbankan syariah ini berdasarkan adanya larangan didalam agama Islam untuk meminjamkan atau memungut pinjaman dengan mengenakan bunga atau yang disebut dengan riba.Sistem pembiayaan pada produk bank syariah khususnya pada produk mudharabah menganut sistem bagi hasil.

Pengetahuan seseorang bisa dipersepsikan secara berbeda oleh orang yang berbeda. Penelitian ini untuk mengetahui respon pegawai mengenai sistem pembiayaan pada produk perbankan syariah.Dari hasil wawancara yang dilakukan kepada pegawai IAIN Parepare menunjukkan bahwa pegawai IAIN Parepare mengetahui informasi sistem pembiayaan atau profil tentang adanya bank syariah. Informasi yang lengkap akan menimbulkan citra atau image yang baik bagi pegawai dalam memilih produk-produk pada bank syariah.

Wawancara dengan Sirajuddin menyampaikan bahwa :

"Iya, saya tahu bank syariah itu adalah bank yang menganut prinsip Islam". ${ }^{6}$

Hal serupa diungkapkan oleh Sunandar, mengatakan bahwa:

"Tahu, karena saya menjadi salah satu nasabah pada bank syariah.Kenapa saya tahu karena pernah menawarkan kredit kepada pegawai dan dosen, dan saya menjadi salah satu nasabah yang mengambil kredit/pembiayaan disana dari banyaknya dosen dan pegawai.Kenapa saya waktu itu tertarik awalnya saya merasa terfasilitas dengan kemudahan prosesnya". 7

Pandangan lain yang serupa diberikan Nur Aeni K., yang mengatakan :

'Sirajuddin (ASN/Pustakawan), 45 Tahun, Wawancara, Parepare, 26 November 2018

${ }^{7}$ Sunandar (Koordinator Bidang Akademik), 42 Tahun, Wawancara, Parepare, 28 November

2018

Banco, Volume 1, Mei 2019 


\section{Fadhliyah Ulfah Rustan, Sitti Jamilah, dan Syahriyah Semaun}

"Ya tahu, yang sistemnya bagi hasil". 8

Produk-produk pembiayaan bank syariah menggunakan empat sistem atau pola yang berbeda :

\section{a. Sistem Bagi Hasil (Investment Financing)}

Konsep bagi hasil yang digambarkan dalam buku Fiqih pada umumnya diasumsikan bahwa para pihak yang bekerja sama bermaksud untuk memulai atau mendirikan suatu usaha patungan (joint venture) ketika semua mitra usaha turut berpartisipasi sejak awal beroperasi dan tetap menjadi mitra usaha sampai usaha berakhir pada waktu semua aset dilikuidasi. Jarang sekali ditemukan konsep usaha yang terus berjalan (running business) ketika mitra usaha bisa datang dan pergi setiap saat tanpa mempengaruhi jalannya usaha.Hal ini disebabkan buku-buku Fiqih Islam ditulis pada waktu usaha tidak sebesar dan serumit usaha zaman sekarang, sehingga konsep "running business" tidak mendapat perhatian.

Namun demikian, itu tidak berarti bahwa konsep bagi hasil tidak dapat diterapkan untuk pembiayaan suatu usaha yang sedang berjalan.Konsep bagi hasil berlandaskan pada beberapa prinsip dasar. Berdasarkan komposisi share modal bank dalam usaha nasabah, terdapat (dua) pola pembayaran, yaitu :

1) Mudharabab

Perjanjian pembiayaan/penanaman dana dari pemilik dana (shabibul maal) kepada pengelola dana (mudharib) untuk melakukan kegiatan usaha tertentu yang sesuai syariah, dengan pembagian hasil usaha antara kedua belah pihak berdasarkan nisbah yang telah disepakati sebelumnya.

Berdasarkan kewenangan yang diberikan kepada pengelola (mudharib), akad kemitraan ini dibagi menjadi dua tipe yaitu:

a) Mudharabah Mutlaqah yaitu pemilik modal memberikan kebebasan penuh kepada pengelola untuk menggunakan modal tersebut dalam usaha yang dianggapnya baik dan menguntungkan.

b) Mudharabah Muqayyad yaitu pemilik modal menentukan syarat dan pembatasan kepada pengelola dalam menggunakan modal tersebut dengan jangka waktu, tempat, jenis usaha dan sebagainya. ${ }^{9}$

2) Musyarakah

Musyarakah merupakan istilah yang sering dipakai dalam konteks skim pembiayaan syariah. Istilah ini berkonotasi lebih terbatas dari pada istilah syirkah yang lebih umum digunakan dalan fikih Islam.Syijirrkah berarti sharing 'berbagi', dan di dalam terminologi Fikih Islam dibagi dalam dua jenis.

a) Syirkah al-milk atau syirkah amlak atau syirkah kepemilikan, yaitu kepemilikan bersama dua pihak atau lebih dari suatu properti; dan

${ }^{8}$ Nur Aeni K. (Staf Perpustakaan), 28 Tahun, Wawancara, Parepare, 26 November 2018

9http:/ / rikiabdulrahman.blogspot.com/2014/01/jenis-jenis-akad-pembiayaan-bank.html 
b) Syirkah al-'aqd atau syikah 'ukud atau syirkah akad, yang berarti kemitraan yang terjadi karena adanya kontrak bersama, atau usaha komersial bersama. Syirkah al-'aqd sendiri ada empat (Mazhab Hambali memasukkan syirkah mudharabah sebagai syirkah al-'aqd yang kelima), satu yang disepakati dan tiga yang diperselisihkan, yaitu:

- Syirkah al-amwal atau syirkah al-Inan, yaitu usaha komersial bersama ketika semua mitra usaha ikut andil menyertakan modal dan kerja, yang tidak harus sama porsinya, ke dalam perusahaan. Para ulama sepakat membolehkan bentuk syirkah ini.

- Syirkah al-mufawadhah, yaitu usaha komersial bersama dengan syarat adanya kesamaan pada penyertaan modal, pembagian keuntungan, pengelolaan, kerja, dan orang. Mazhab Hanafi dan Maliki membolehkan bentuk syirkah ini. Sementara itu, mazhab Syafi'i dan Hambali melarangnya karena secara realita sukar terjadi persamaan pada semua unsurnya, dan banyak mengandung unsur gharar atau ketidakjelasan.

- Syirkah al-a'mal atau syirkah Abdan, yaitu usaha komersial bersama ketika semua mitra usaha ambil bagian dalam memberikan jasa kepada pelanggan. Jumbur (mayoritas) ulama, yaitu dari mazhab Hanafi, Maliki dan Hambali, membolehkan bentuk syirkah ini. Sementara itu, mazhab Syafi'i melarangnya karena mazhab ini hanya membolehkan syirkah modal dan tidak boleh syirkah kerja.

- Syirkah al-wujuh adalah usaha komersial bersama ketika mitra tidak mempunyai investasi sama sekali. Mereka membeli komoditas dengan pembayaran tangguh dan menjualnya tunai. Mazhab Hanafi dan Hambali membolehkan bentuk syirkah ini, sedangkan mazhab Maliki dan Syafi'I melarangnya.

\section{b. Sistem Jual Beli (Trade Financing)}

Jual beli (buyu', jamak dari bai) atau perdagangan atau perniagaan atau trading secara terminologi Fiqih Islam berarti tukar menukar harta atas dasar saling ridha (rela), atau memindahkan kepemilikan dengan imbalan pada sesuatu yang diizinkan.

Dari sisi objek yang diperjualbelikan, jual beli dibagi tiga, yaitu:

1) Jual beli mutlaqah, yaitu pertukaran antara barang atau jasa dengan uang;

2) Jual beli sharf, yaitu jual beli atau pertukaran antara satu mata uang dengan mata uang lain;

3) Jual beli muqayyadah, yaitu jual beli dimana pertukaran terjadi antara barang dengan barang (barter), atau pertukaran antara barang dengan barang yang dinilai dengan valuta asing (counter trade);

Dari sisi cara menetapkan harga, jual beli dibagi empat, yaitu:

1) Jual beli musawamah (tawar menawar), yaitu jual beli biasa ketika penjual tidak memberitahukan harga pokok dan keuntungan yang didapatnya; 


\section{Fadhliyah Ulfah Rustan, Sitti Jamilah, dan Syahriyah Semaun}

2) Jual beli amanah, yaitu jual beli dimana penjual memberitahukan modal jualnya (harga perolehan barang). Jual beli amanah ada tiga, yaitu:

(a) Jual beli murabahah, yaitu jual beli ketika penjual menyebutkan harga pembelian barang (termasuk biaya perolehan) dan keuntungan yang diinginkan;

(b) Jual beli muwadha'ah (discount), yaitu jual beli dengan harga dibawah modal dengan jumlah kerugian yang diketahui, untuk penjualan barang atau aktiva yang nilai bukunya sudah sangat rendah;

(c) Jual beli tauliyah, yaitu jual beli dengan harga modal tanpa keuntungan dan kerugian.

Dari sisi cara pembayaran, jual beli dibagi empat, yaitu:

1) Jual beli tunai dengan penyerahan barang dan pembayaran langsung;

2) Jual beli dengan pembayaran tertunda, bai' muajjal (deferred payment), yaitu jual beli dengan penyerahan barang secara langsung (tunai), tetapi pembayaran dilakukan kemudian dan bisa dicicil;

3) Jual beli dengan penyerahan barang tertunda (deferred delivery), yang meliputi:

(a) Bai' as salam, yaitu jual beli ketika pembeli membayar tunai di muka atas barang yang dipesan (biasanya produk pertanian) dengan spesifikasinya yang akan diserahkan kemudian; dan

(b) Bai' al istishna, yaitu jual beli dimana pembeli membayar tunai atau bertahap atas barang yang dipesan (biasanya produk manufaktur) dengan spesifikasinya yang harus diproduksi dan diserahkan kemudian.

4) Jual beli dengan penyerahan barang dan pembayaran sama-sama tertunda.

Namun demikian, bentuk jual beli yang diadopsi dalam perbankan syariah dalam pemberian pembiayaan secara luas ada tiga, yaitu bai' al murabahah (biasa disebut murabahah saja), bai' as salam (biasa disebut salam saja), dan bai' al istishna (biasa disebut istishna saja). Sedangkan, bai' al sharf (biasa disebut sharf saja) diterapkan dalam jasa pertukaran uang (money changer).

\section{1) Murabahah}

Murabahah adalah istilah dalam Fiqih Islam yang berarti suatu bentuk jual beli tertentu ketika penjual menyatakan biaya perolehan barang, meliputi harga barang dan biaya-biaya lain yang dikeluarkan untuk memperoleh barang tersebut, dan tingkat keuntungan (margin) yang diinginkan.

Tingkat keuntungan ini bisa dalam bentuk lumpsum atau persentase tertentu dari biaya perolehan. Pembayaran bisa dilakukan secara spot (tunai) atau bisa dilakukan di kemudian hari yang disepakati bersama. Murabahah pada awalnya merupakan konsep jual beli yang sama sekali tidak ada hubungannya dengan pembiayaan. Dalam pembiayaan ini, bank sebagai pemilik dana membelikan barang sesuai dengan spesifikasi yang diinginkan oleh nasabah yang 
membutuhkan pembiayaan, kemudian menjualnya ke nasabah tersebut dengan penambahan keuntungan tetap. Sementara itu, nasabah akan mengembalikan hutangnya di kemudian hari secara tunai maupun cicil.

\section{2) Salam}

Salam merupakan bentuk jual beli dengan pembayaran di muka dan penyerahan barang di kemudian hari (advanced payment atau forward buying atau future sales) dengan harga, spesifikasi, jumlah, kualitas, dan tanggal dan tempat penyerahan yang jelas, serta disepakati sebelumnya dalam perjanjian.

Barang yang diperjualbelikan belum tersedia pada saat transaksi dan harus diproduksi terlebih dahulu, seperti produk-produk pertanian dan produk-produk fungible (barang yang dapat diperkirakan dan diganti sesuai berat, ukuran, dan jumlahnya) lainnya.Risiko terhadap barang yang diperjualbelikan masih berada pada penjual sampai waktu penyerahan barang. Pihak pembeli berhak untuk meneliti dan dapat menolak barang yang akan diserahkan apabila tidak sesuai dengan spesifikasi awal yang disepakati.

Salam diperbolehkan oleh Rasululluah SAW dengan beberapa syarat yang harus dipenuhi.

Salam bermanfaat bagi penjual karena mereka menerima pembayaran di muka. Salam juga bermanfaat bagi pembeli karena pada umumnya harga dengan akad salam lebih murah daripada harga dengan akad tunai. Salam dimaksudkan sebagai bentuk pembiayaan untuk memenuhi kebutuhan pedagang dan petani kecil sebagai penjual yang membutuhkan modal awal untuk dapat menjalankan usahanya untuk memenuhi pesanan pembeli. Bentuk pembiayaan salam ini dapat juga dilakukan oleh perbankan syariah modern, khususnya untuk membiayai sektor pertanian. Bank syariah dapat mengambil keuntungan dari perbedaan harga salam yang lebih rendah daripada harga tunai. Untuk memastikan penyerahan barang pada tanggal yang ditentukan, bank dapat meminta jaminan. Karena dalam sistem salam ini bank (sebagai penjual/muslam ilaib) menerima pesanan barang dari nasabah (pembeli/muslam), kemudian bank (sebagai pembeli/muslam) memesankan permintaan barang nasabah kepada produsen penjual (muslam ilaib) dengan pembayaran di muka, dengan jangka waktu penyerahan yang disepakati bersama.

\section{3) Istishna}

Istishna adalah memesan kepada perusahaan untuk memproduksi barang atau komoditas tertentu untuk pembeli/pemesan.Istishna merupakan salah satu bentuk jual beli dengan pemesanan yang mirip dengan salam yang merupakan bentuk jual beli forward kedua yang dibolehkan oleh syariah. 


\section{Fadhliyah Ulfah Rustan, Sitti Jamilah, dan Syahriyah Semaun}

Jika perusahaan mengerjakan untuk memproduksi barang yang dipesan dengan bahan baku dari perusahaan, maka kontrak/akad istishna muncul. Agar akad istishna menjadi sah, harga harus ditetapkan di awal sesuai kesepakatan dan barang harus memiliki spesifikasi yang jelas yang telah disepakati bersama.Dalam istishna pembayaran dapat di muka, dicicil sampai selesai, atau di belakang, serta istishna biasanya diaplikasikan untuk industri dan barang manufaktur.

Sistem istishna menciptakan kewajiban moral bagi perusahaan untuk memproduksi barang pesanan pembeli. Sebelum perusahaan mulai memproduksinya, setiap pihak dapat membatalkan kontrak dengan memberitahukan sebelumnya kepada pihak yang lain. Namun demikian, apabila perusahaan sudah memulai produksinya, kontrak istishna tidak dapat diputuskan secara sepihak.

Sebagai bentuk jual beli forward, istishna mirip dengan salam. Namun, ada beberapa perbedaan di antara keduanya, antara lain:

Obyek istishna selalu barang yang harus diproduksi, sedangkan obyek salam bisa untuk barang apa saja, baik harus diproduksi lebih dahulu maupun tidak diproduksi lebih dahulu.

a) Harga dalam sistem salam harus dibayar penuh di muka, sedangkan harga dalam sistem istishna tidak harus dibayar penuh di muka, melainkan dapat juga dicicil atau dibayar di belakang;

b) Sistem salam efektif tidak dapat diputuskan secara sepihak, sedangkan dalam istishna dapat diputuskan sebelum perusahaan mulai memproduksi; dan

c) Waktu penyerahan yang tertentu merupakan bagian penting dari salam, namun dalam istishna tidak merupakan keharusan.

Apabila terjadi keterlambatan penyerahan harga dapat dipotong sejumlah tertentu per hari keterlambatan. Dalam aplikasinya bank syariah melakukan istishna, yaitu bank (sebagai penerima pesanan/shani') menerima pesanan barang dari nasabah (pemesan/mustashni'), kemudian bank (sebagai pemesan/mustashni) memesankan permintaan barang nasabah kepada produsen penjual (shani') dengan pembayaran di muka, cicil, atau di belakang, dengan jangka waktu penyerahan yang disepakati bersama.

\section{c. Sistem Sewa (Trade Financing)}

Transaksi nonbagi hasil selain yang berpola jual beli adalah transaksi berpola sewa atau ijarah.Ijarah, biasa juga disebut sewa, jasa, atau imbalan, adalah akad yang dilakukanvatas dasar suatu manfaat dengan imbalan jasa.Ijarah adalah istilah dalam Fikih Islam dan berarti memberikan sesuatu untuk disewakan.

Ada dua jenis ijarah dalam hukum Islam, yaitu:

1) Ijarah yang berhubungan dengan sewa jasa, yaitu mempekerjakan jasa seseorang dengan upah sebagai imbalan jasa yang disewa. Pihak yang mempekerjakan disebut mustajir, pihak pekerja disebut ajir, upah yang dibayarkan disebut ujrah. 
2) Ijarah yang berhubungan dengan sewa aset atau properti, yaitu memindahkan hak untuk memakai dari aset atau properti tertentu kepada orang lain dengan imbalan biaya sewa. Bentuk ijarah ini mirip dengan leasing (sewa) di bisnis konvensional. Pihak yang menyewa (lessee) disebut musta'jir, pihak yang menyewakan (lessor) disebut mu'jir/muaajir, sedangkan biaya sewa disebut ujrah.

Ijarah bentuk pertama banyak diterapkan dalam pelayanan jasa perbankan syariah.Sementara itu, ijarah bentuk kedua biasa dipakai sebagai bentuk investasi atau pembiayaan di perbankan syariah.

Tabel 4.2

Perbedaan Ijarah dan Leasing

\begin{tabular}{|c|c|c|c|}
\hline No. & Item & Ijarah & Leasing \\
\hline 1. & Objek & $\begin{array}{l}\text { Manfaat barang } \\
\text { dan jasa }\end{array}$ & Manfaat barang saja \\
\hline 2. & $\begin{array}{l}\text { Alih } \\
\text { Kepemilikan }\end{array}$ & $\begin{array}{l}\text { Jelas: } \\
\text { 1. Ijarah - tidak } \\
\text { ada } \\
\text { 2. IMBT - ada }\end{array}$ & $\begin{array}{l}\text { Tidak semuanya jelas } \\
: \\
\text { 1. Operating Lease - } \\
\text { tidak ada } \\
\text { 2. Financial Lease - } \\
\text { ada pilihan untuk } \\
\text { membeli atau tidak } \\
\text { pada akhir periode }\end{array}$ \\
\hline 3. & Sewa Beli & $\begin{array}{l}\text { Tidak boleh } \\
\text { karena ada } \\
\text { unsur gharar } \\
\text { (tidak jelas) } \\
\text { antara sewa dan } \\
\text { beli }\end{array}$ & Boleh \\
\hline 4. & $\begin{array}{l}\text { Sale dan Lease } \\
\text { Back }\end{array}$ & Boleh & Boleh \\
\hline
\end{tabular}

1. Ijarah

Sewa atau ijarah dapat dipakai sebagai bentuk pembiayaan, pada mulanya bukan merupakan bentuk pembiayaan, tetapi merupakan aktivitas usaha seperti jual beli. Individu yang membutuhkan pembiayaan untuk membeli aset dapat mendatangi pemilik dana (dalam hal ini bank) untuk membiayai pembelian aset produktif..Gambar 4.7 menunjukkan skema pembiayaan Ijarah.

2. Ijarah wa Iqtina atau Ijarah muntabiya bittamlik. (IMBT) Ijarah wa Iqtina atau Ijarah Muntabiya Bittamlik. (IMBT) adalah transaksi sewa dengan perjanjian untuk menjual atau menghibahkan obyek sewa di akhir periode 


\section{Fadhliyah Ulfah Rustan, Sitti Jamilah, dan Syahriyah Semaun}

sehingga transaksi ini diakhiri dengan alih kepemilikan obyek sewa. Berbagai bentuk alih kepemilikan IMBT antara lain:

a) Hibah di akhir periode, yaitu ketika pada akhir periode sewa aset dihibahkan kepada penyewa;

b) Harga yang berlaku pada akhir periode, yaitu ketika pada akhir periode sewa aset dibeli oleh penyewa dengan harga yang berlaku pada saat itu

c) Harga ekuivalen dalam periode sewa, yaitu ketika penyewa membeli aset dalam periode sewa sebelum kontrak sewa berakhir dengan harga ekuivalen; dan

d) Bertahap selama periode sewa, yaitu ketika alih kepemilikan dilakukan bertahap dengan pembayaran cicilan selama periode sewa.

\section{d. Sistem Pinjaman (Dana Talangan)}

Sistem berbentuk pinjaman atau dana talangan yang diterapkan dalam perbankan syariah adalah Qardh dan turunannya Qardhul Hasan. Karena bunga dilarang dalam Islam, maka pinjaman Qardh maupun Qardbul Hasan merupakan pinjaman tanpa bunga.Lebih khusus lagi, pinjaman Qardhul Hasan merupakan pinjaman kebajikan yang tidak bersifat komersial, tetapi bersifat sosial.

Qardh merupakan pinjaman kebajikan/lunak tanpa imbalan, biasanya untuk pembelian barang-barang fungible (yaitu barang yang dapat diperkirakan dan diganti sesuai berat, ukuran, dan jumlahnya).

Sistem ini digunakan oleh IDB ketika memberikan pinjaman lunak kepada pemerintah. Biaya jasa ini pada umumnya tidak lebih dari 2,5 persen, dan selama ini berkisar antara 1-2 persen. Dalam aplikasinya di perbankan syariah, qardh biasa digunakan untuk menyediakan dana talangan kepada nasabah prima dan untuk menyumbang sektor usaha kecil/mikro atau membantu sektor sosial. Dalam hal yang terakhir, skema pinjamannya disebut qardhul hasan.

Rukun dari Qardh atau Qardhul Hasan yang harus dipenuhi dalam transaksi ada beberapa :

1) Pelaku, yaitu muqtaridh (peminjam), pihak yang membutuhkan dana, dan muqridh (pemberi pinjaman), pihak yang memiliki dana;

2) Objek, yaitu qardh (dana);

3) Tujuan, yaitu 'iwad atau countervalue berupa pinjaman tanpa imbalan (pinjam Rp.

X,- dikembalikan Rp. X,-); dan

4) Shighah, yaitu Ijab dan Qabul.

Sedangkan syarat dari akad Qardh atau Qardhul Hasan yang harus dipenuhi dalam transaksi, yaitu:

1) Kerelaan kedua belah pihak; dan

2) Dana digunakan untuk sesuatu yang bermanfaat dan halal.

Pinjaman qardh biasanya diberikan oleh bank kepada nasabahnya sebagai fasilitas pinjaman talangan pada saat nasabah mengalami overdraft. Fasilitas ini dapat 
merupakan bagian dari satu paket pembiayaan lain, untuk memudahkan nasabah bertransaksi.

Sirajuddin mengatakan bahwa :

"Dari teman-teman kantor, di kampus juga karena ada jurusan perbankan syariah.Karena itu juga saya tahu ada yang dinamakan bank syariah". ${ }^{10}$

Hal serupa diungkapkan oleh Fatmawati, yang mengatakan:

"Dari seorang mahasiswa yang membuka bank mini di kampus.Dia menawarkan produk syariah kepada saya, sehingga saya tertarik untuk membuka tabungan syariah dan sampai sekarang saya ketagihan menjadi nasabah tetapnya". ${ }^{11}$

Tambahan wawancara dari fatmawati bahwa:

"Pada saat melakukan pembukaan rekening di bank syariah mandiri parepare yaitu fotocopy KTP, fotocopy KK dan kemudahan dana awal atas tabungan sebanyak Rp 100.000,00". ${ }^{12}$

Adapun produk-produk pada bank syariah mandiri adalah tabungan, giro, deposito, mandiri syariah priority, pembiayaan konsumen, investasi, tabungan emas, tabungan haji \& umroh, jasa produk dan jasa operasional.

Pihak perbankan syariah selain melakukan sosialisasi ke IAIN Parepare, juga telah melaksanakan MOU (Momerandum Of Understanding) dengan instansi terkait dengan IAIN Parepare seperti bank syariah mandiri, bank muamalat, dan BNI syariah Parepare.

Sosialisasi bank dan melalui brosur/iklan juga memegang peranan dalam pemberian informasi kepada pegawai IAIN Parepare.Kenyataan tersebut diungkapkan Nur Aeni K. melalui wawancara dengan peneliti.

"Dari sosialisasi bank syariah ke kantor yang pernah ada di kampus". ${ }^{13}$ Hal tersebut dibenarkan oleh Subhan Saleh di meja kerjanya yangmengatakan:

"Awalnya dari brosur oleh salah satu bank syariah di Makassar tahun $2006 " .{ }^{14}$

${ }^{10}$ Sirajuddin (ASN/Pustakawan), 45 Tahun, Wawancara, Parepare, 26 November 2018

${ }^{11}$ Fatmawati (Staf Perpustakaan), 30 Tahun, Wawancara, Parepare, 30 November 2018

${ }^{12}$ Fatmawati (Staf Perpustakaan), 30 Tahun, Wawancara, Parepare, 30 November 2018

${ }^{13}$ Nur Aeni K. (Staf Perpustakaan), 28 Tahun, Wawancara, Parepare, 26 November 2018

${ }^{14}$ Subhan Saleh (Pustawakan), 32 Tahun, Wawancara, Parepare, 28 November 2018

Banco, Volume 1, Mei 2019 


\section{Fadhliyah Ulfah Rustan, Sitti Jamilah, dan Syahriyah Semaun}

Tanggapan responden menunjukkan bahwa sebagian besar responden memberikan tanggapan positif.Kondisi ini memberikan kesan bahwa respon pegawai mengenai perbankan syariah dipersepsikan secara positif oleh responden.

Dari wawancara dengan Ilhamah Felayati, mengatakan bahwa:

"Saat ini produk perbankan syariah belum memuaskan, masih banyak produk perbankan syariah yang copy paste dari produk bank konvensional, produk yang ditawarkan belum memiliki karakteristik sebagai produk perbankan syariah.Produk perbankan syariah dengan produk bank konvensional dibedakan oleh penggunaan akad dalam setiap transaksi produk tersebut". ${ }^{15}$

Lain halnya dengan Nining Artianasari, mengatakan bahwa:

"Saat ini produk perbankan syariah belum sebanyak produk bank konvensional sehingga belum banyak alternatif pilihan bagi pegawai dalam bertransaksi perbankan, berbeda dengan konvensional seperti bank Mandiri, BNI, BRI, produk bank tersebut memang dibutuhkan oleh pegawai. Produk simpanan di bank syariah belum memiliki variasi produk sesuai kebutuhan, inovasi produk di bank syariah masih sangat kurang". ${ }^{16}$

\section{Bentuk Fasilitas Produk Pembiayaan Bank Syariah}

Respon pegawai yang menganggap bahwa fasilitas produk pembiayaan bank syariah menguntungkan nasabah yang menggunakan produk pembiayaan untuk usaha/investasinya yang didapat dari bank syariah pada akhirnya saat pengembalian dana tersebut bila dihitung-hitung ternyata lebih banyak jumlahnya bila dibandingkan dari sistem bunga pada bank konvensional, sehingga nasabah merasa rugi, dan akhirnya memilih bank konvensional sebagai tempat untuk mengambil produk pembiayaannya.

Ada sebagian pegawai IAIN Parepare menjadi nasabah bank syariah yang kecewa dan mengeluhkan laporan pembayaran angsuran yang diberikan bank syariah, yang ternyata setiap membayar angsuran pinjaman pada awal-awal tahun perjanjian pembiayaan sebagian besar hanya membayar bunganya saja dan untuk pembayaran pokoknya hanya sedikit sekali, sehingga outstanding pokok pinjaman-nya turun tidak signifikan. Untuk itu mereka mau mengalihkan hutangnya ke bank konvensional, karena di bank konvensional setiap membayar angsuran antara pembayaran pokok dengan pembayaran margin hampir berimbang, sehingga penurunan outstanding pokok pinjamannya signifikan. Hal ini terungkap saat peneliti mewawancarai Sunandar :

${ }^{15}$ Ilhamah Felayati (Staf Perpustakaan), 29 Tahun, Wawancara, Parepare, 03Desember 2018

${ }^{16}$ Nining Artianasari (Staf Administrasi), 28 Tahun, Wawancara, Parepare, 30 November 2018 
“.... tapi yang membuat saya kecewa, waktu itu karena saya sudah bayar 2 tahun tapi kenapa utang saya masih ada sekitaran 72an juta gitu. Jadi saya tanya dan menariknya mereka bilang yang saya bayar itu katanya masih bunganya, tapi entah apalah namanya. Ya seperti yang saya katakan tadi itu hanya perbedaan namanya sajalah". ${ }^{17}$

Lain halnya dengan Nur Aeni, yang mengatakan bahwa:

"Potongan tidak berat, beda dengan potongan bank lain banyak sekali". ${ }^{18}$

Hal ini juga dibenarkan oleh Nining Artianasari, yang mengatakan bahwa:

"Potongan yang diberikan sangat kecil karena tidak memberatkan". ${ }^{19}$

Respon positif dari sebagian pegawai IAIN Parepare akan jasa keuangan syariah telah membawa mereka pada satu kebutuhan untuk mengalihkan dana yang selama ini mereka simpan di lembaga keuangan konvensional ke lembaga keuangan syariah. Bank yang berasaskan Islam sebagai salah satu lembaga keuangan yang mampu melayani nasabah dengan menyediakan produk pembiayaan dengan akad bagi hasil.

Respon sebagian pegawai IAIN Parepare yang kurang memahami konsep sistem bagi hasil sehingga mereka menilai bahwa operasional bank syariah masih kalah dengan bank konvensional baik kualitas maupun kuantitasnya.

Pada dasarnya fungsi utama bank syariah tidak jauh berbeda dengan bank konvensional yaitu menghimpun dana (funding) dari masyarakat kemudian menyalurkannya kembali atau lebih dikenal sebagai fungsi intermediasi. Dalam prakteknya bank syariah menyalurkan dana yang diperolehnya dalam bentuk pemberian pembiayaan (financing) dan jasa (service). Pembiayaan dalam perbankan syariah dapat dibagi tiga :

a. Return bearing financing, yaitu bentuk pembiayaan yang secara komersial menguntungkan, ketika pemilik modal mau menanggung risiko kerugian dan nasabah juga memberikan keuntungan.

b. Return free financing, yaitu bentuk pembiayaan yang tidak untuk mencari keuntungan yang lebih ditujukan kepada orang yang membutuhkan (poor), sehingga tidak ada keuntungan yang dapat diberikan.

c. Charity financing, yaitu bentuk pembiayaan yang memang diberikan kepada orang miskin dan membutuhkan, sehingga tidak ada klaim terhadap pokok dan keuntungan.

Konsep bagi hasil menurut pegawai IAIN Parepare merupakan salah satu instrumen produk perbankan syariah yang bersifat menguntungkan, dimana konsep ini memberikan

${ }^{17}$ Sunandar (Koord. Bid. Akademik), 42 Tahun, W awancara, Parepare, 28 November 2018

${ }^{18}$ Nur Aeni K. (Staf Perpustakaan), 28 Tahun, Wawancara, Parepare, 26 November 2018

${ }^{19}$ Nining Artianasari (Staf Administrasi), 28 Tahun, Wawancara, Parepare, 30 November 2018

Banco, Volume 1, Mei 2019 


\section{Fadhliyah Ulfah Rustan, Sitti Jamilah, dan Syahriyah Semaun}

keuntungan yang rata antara bank dan nasabah, kedua belah pihak tidak melakukan dominasi atau tindakan penzoliman satu pihak atas pihak lain.

Didalam menjalankan operasinya fungsi bank Islam akan terdiri dari:

a. Sebagai penerima amanah untuk melakukan investasi atas dana-dana yang dipercayakan oleh pemegang rekening investasi / deposan atas dasar prinsip bagi hasil sesuai dengan kebijakan investasi bank.

b. Sebagai pengelola investasi atas dana yang dimiliki oleh pemilik dana / sahibul mal sesuai dengan arahan investasi yang dikehendaki oleh pemilik dana (dalam hal ini bank bertindak sebagai manajer investasi).

c. Sebagai penyedia jasa lalu lintas pembayaran dan jasa-jasa lainnya sepanjang tidak bertentangan dengan prinsip syariah.

d. Sebagai pengelola fungsi sosial seperti pengelolaan dana zakat dan penerimaan serta penyaluran dana kebajikan (fungsi optional).

Dari fungsi tersebut maka produk bank Islam terdiri dari :

a. Prinsip mudharabah yaitu perjanjisn antara dua pihak dimana pihak pertama sebagai pemilik dana/sahibul mal dan pihak kedua sebagai pengelola dana/mudharib untuk mengelola suatu kegiatan ekonomi dengan menyepakati nisbahbagi hasil atas keuntungan yang akan diperoleh sedangkan kerugian yang timbul adalah resiko pemilik dana sepanjang tidak terdapat bukti bahwa mudharib melakukan kecurangan atau tindakan yang tidak amanah (misconduct). Berdasarkan kewenangan yang diberikan kepada mudharib maka mudharabah dibedakan menjadi mudharabah mutlaqah dimana mudharib diberikan kewenangan sepenuhnya untuk menentukan pilihan investasi yang dikehendaki, sedangkanjenis yang lain adalah mudharabah muqayyaddah dimana arahan investasi ditentukan oleh pemilik dana sedangkan mudharib bertindak sebagai pelaksana/pengelola.

b. Prinsip Musyarakah yaitu perjanjian antara pihak-pihak untuk menyertakan modal dalam suatu kegiatan ekonomi dengan pembagian keuntungan atau kerugian sesuai nisbah yang disepakati Musyarakah dapat bersifat tetap atau bersifat temporer dengan penurunan secara periodik atau sekaligus diakhir masa proyek.

c. Prinsip Wadiah adalah titipan dimana pihak pertama menitipkan dana atau benda kepada pihak kedua selaku penerima titipan dengan konsekuensi titipan tersebut sewaktu-waktu dapat diambil kembali, dimana penitip dapat dikenakan biaya penitipan. Berdasarkan kewenangan yang diberikan maka wadiah dibedakan menjadi wadiah yat dhamanah yang berarti penerima titipan berhak mempergunakan dana/barang titipan untuk didayagunakan tanpa ada kewajiban penerima titipan untuk memberikan imbalan kepada penitip dengan tetap pada kesepakatan dapat diambil setiap saat diperlukan, sedang disisi lain wadiah amanah tidak memberikan kewenangan kepada penerima titipan untuk mendayagunakan barang/dana yang dititipkan. 
d. Prinsip Jual Beli (Al Buyu') yaitu terdiri dari:Murabahah yaitu akad jual beli antara dua belah pihak dimana pembeli dan penjual menyepakati harga jual yang terdiri dari harga beli ditambah ongkos pembelian dan keuntungan bagi penjual. Murababah dapat dilakukan secara tunai bisa juga secara bayar tangguh atau bayar dengan angsuran. Salam yaitu pembelian barang dengan pembayaran dimuka dan barang diserahkan.Ishtisna' yaitu pembelian barang melalui pesanan dan diperlukan proses untuk pembuatannya sesuai dengan pesanan pembeli dan pembayaran dilakukan dimuka sekaligus atau secara bertahap. ${ }^{20}$

e. Jasa-Jasa terdiri dari:Ijarah yaitu kegiatan penyewaan suatu barang dengan imbalan pendapatan sewa, bila terdapat kesepakatan pengalihan pemilikan pada akhir masa sewa disebut Ijarah mumtahiya bi tamlik (sama dengan operating lease). Wakalah yaitu pihak pertama memberikan kuasa kepada pihak kedua (sebagai wakil) untuk urusan tertentu dimana pihak kedua mendapat imbalan berupa fee atau komisi. Kafalah yaitu pihak pertama bersedia menjadi penanggung atas kegiatan yang dilakukan oleh pihak kedua sepanjang sesuai dengan yang diperjanjikan dimana pihak pertama menerima imbalan berupa fee atau komisi (garansi). Sharf yaitu pertukaran /jual beli mata uang yang berbeda dengan penyerahan segera /spot berdasarkan kesepakatan harga sesuai dengan harga pasar pada saat pertukaran

f. Prinsip Kebajikan yaitu penerimaan dan penyaluran dana kebajikan dalam bentuk zakat infaq shodaqah dan lainnya serta penyaluran alqardul hasan yaitu penyaluran dan dalam bentuk pinjaman untuk tujuan menolong golongan miskin dengan penggunaan produktif tanpa diminta imbalan kecuali pengembalian pokok hutang.

Fasilitas-fasilitas produk pembiayaan di bank syariah mandiri terdiri dari:

a. Pemberian fasilitas pembiayaan konsumer dengan pola channeling kepada sejumlah karyawan (kolektif) dengan rekomendasi Perusahaan.

b. Limit pembiayaan minimum sebesar Rp5 juta dan maksimum sebesar Rp250 juta per calon nasabah

c. Jangka waktu pembiayaan

Persyaratan Administrasi

a. Mengisi formulir permohonan pembiayaan;

b. Fotocopy KTP calon nasabah dan pasangan (perorangan) / KTP pengurus (non perorangan);

c. Fotocopy Surat Nikah dan Kartu Keluarga (perorangan);

${ }^{20}$ www.bcasyariah.co.id, http:/ /www.bcasyariah.co.id/2011/04/prinsip-dasar-operasionalperbankan-syariah/ . (Akses 02/01/2019). 


\section{Fadhliyah Ulfah Rustan, Sitti Jamilah, dan Syahriyah Semaun}

d. Fotocopy NPWP Pribadi (perorangan) atau NPWP Perusahaan dan Pengurus (non perorangan);

e. SIUP, TDP dan Surat Keterangan Domisili;

f. Fotocopy Akta Pendirian / Anggaran dasar dan perubahannya (non perorangan);

g. Fotocopy pengesahan dari Instansi yang berwenang (non perorangan);

h. Laporan keuangan/ laporan usaha 3 periode terakhir;

i. Fotocopy mutasi rekening buku tabungan/statement giro 6 bulan terakhir;

j. Bukti legalitas jaminan (SHM/bilyet deposito/jaminan lainnya);

k. Bukti-bukti purchase order atau Surat Perintah Kerja (SPK) jika ada. ${ }^{21}$

Penentuan bagi hasil yang berlaku dapat ditentukan dengan langkah berikut:

a. Penentuan besarnya rasio bagi hasil dibuat pada waktu akad dengan berpedoman pada kemungkinan untung dan rugi

b. Besarnya rasio bagi hasil berdasarkan pada jumlah keuntungan yang diperoleh

c. Besarnya penetapan porsi bagi hasil antara kedua belah pihak ditentukan sesuai kesepakatan bersama, dan harus terjadi dengan adanya kerelaan (An-Taradhin)di masing-masing pihak tanpa adanya unsur paksaan.

d. Bagi hasil tergantuk pada keuntungan proyek yang di jalankan sekiranya itu tidak mendapatkan keuntungan maka kerugian ditanggung bersama oleh kedua belah pihak.

Jumlah pembagian laba meningkat sesuai dengan peningkatan jumlah pendapatan

\section{Tanggapan Pegawai IAIN Parepare Terhadap Produk Pembiayaan Bank Syariah}

Berdasarkan hasil wawancara yang telah dilakukan peneliti kepada sejumlah pegawai di IAIN Parepare diperoleh informasi bahwa perlu adanya peningkatan dan mengintensifkan kegiatan promosi melalui berbagai media agar lebih banyak lagi masyarakat yang mengenal produk pembiayaan syariah serta lebih dapat bersaing dengan produk pembiayaan kompetitor. Karena selama ini citra (image) bank syariah di masyarakat sebagai bank yang tidak jauh bedadengan bank konvensional. Sehingga perlu promosi yang lebih gencar dan intensif lagi untuk terus memperkenalkan produk-produk bank dengan mengembangkan nilai-nilai syariah yang bersifat universal yaitu adanya aspek keadilan, transparansi, dan menghindari kegiatan spekulatif dalam bertransaksi secara umum dengan menerapkan sistem bagi hasil agar pangsa pasar semakin luas. Hal ini senada dengan yang diungkapkan oleh Subhan, mengatakan bahwa:

"Harapan saya mungkin bank syariah disetarakan atau lebih bagus dari bank konvensional serta promosi juga lebih ditingkatkan", ${ }^{22}$

\footnotetext{
${ }^{21}$ www.bankmuamalat.co.id, http:/ /www.bankmuamalat.co.id/pembiayaan-retail/pembiayaanib-muamalat-modal-kerja.(Akses 02/01/2019).

22 Subhan Saleh (Pustawakan), 32 Tahun, Wawancara, Parepare, 28 November 2018
} 
Lain halnya dengan Sunandar, mengatakan bahwa:

"Saya kira semua bank syariah itu meniru bank konvensional, dimana mereka dapat keuntungan kalau bukan dengan bunga. Dan saya harap ketika prospek harus sesuai dengan kenyataan". 23

Selain promosi, pegawai IAIN Parepare juga berharap agar proses pembukaan produk pembiayaan lebih dipermudah dan fasilitas-fasilitas yang diberikan lebih ditingkatkan lagi.

Senada dengan hal tersebut, Nining Artianasari menaggapipula :

"Bank yang berdasarkan prinsip islam dalam hal transparansi belum diwujudkan sehingga saya sebagai nasabah beralih menabung di bank konvensional karena pelayanan dan sosialisasi bank konvensioal lebih bagus dibandingkan bank syariah". ${ }^{24}$

Praktik sekarang yang dilakukan oleh sebagian industri keuangan syariah, produk yang ditawarkannya ada yang masih belum sesuai dengan konsep dasar bank syariah itu sendiri.Akan tetapi, adapula yang mengetahui tentang keharaman bunga dan diganti bagi hasil.Hal ini bisa jadi dikarenakan faktor SDM yang belum memahami bentuk teori dan konsep dari bank syariah.Sehingga praktik di lapangan mengindikasikan kemiripan antara produk bank syariah dengan produk bank konvensional. Kondisi seperti ini memang perlu diluruskan sehingga tidak ada kesan bahwa praktik bank syariah dengan produk pada bank konvensional sama.

Wawancara dengan Sunandar menyampaikan bahwa :

"Saat ini biaya yang dikenakan bank Syariah masih mahal khususnya dalam pembiayaan. Bank syariah seharusnya menetapkan harga berdasarkan perhitungan bagi hasil yang diperoleh dari produktif yang dimiliki, sehingga bank syariah memiliki perbedaan dengan bank konvensional". 25

Tanggapanlain dari Nur Aeni K., mengatakan bahwa:

"Menggunakan bank syariah sangat bermanfaat sekali, karena tidak ada potongan dan sistemnya bagi hasil". 26

Ada juga salah satu istilah dalam perbankan syariah yaitu profit sharing. Profit sharing adalah perhitungan bagi hasil yang didasarkan kepada hasil net dari total pendapatan

${ }^{23}$ Sunandar (Koord. Bid. Akademik), 42 Tahun, Wawancara, Parepare, 28 November 2018

${ }^{24}$ Nining Artianasari (Staf Administrasi), 28 Tahun, Wawancara, Parepare, 30 November 2018

${ }^{25}$ Sunandar (Koordinator Bidang Akademik), 42 Tahun, Wawancara, Parepare, 28 November

2018.

${ }^{26}$ Nur Aeni K. (Staf Perpustakaan), 28 Tahun, Wawancara, Parepare, 26 November 2018.

Banco, Volume 1, Mei 2019 


\section{Fadhliyah Ulfah Rustan, Sitti Jamilah, dan Syahriyah Semaun}

setelah dikurangi dengan biaya-biaya yang dikeluarkan untuk memperoleh pendapatan tersebut. Apabila suatu bank menggunakan sistem profit sharing, kemungkinan yang akan terjadi adalah bagi hasil yang akan diterima shabibul mal akan semakin kecil. ${ }^{27}$ Kondisi ini akan mempengaruhi keinginan masyarakat untuk mengivestasikan dananya pada bank syariah yang berdampak menurunnya jumlah dana pihak ketiga secara keseluruhan.

Respon merupakan suatu kegiatan (activity) atau reaksi feedback yang dilakukan seseorang terhadap rangsangan, atau perilaku yang dihadirkan rangsangan. ${ }^{28}$ Respon dapat dikemukakan karena perasaan, kemampuan berpikir, pengalaman yang tidak sama dalam melakukan umpan balik antar individu satu dengan individu lainnya. Poerdawarminta, respon diartikan sebagai tanggapan, reaksi dan jawaban. ${ }^{29}$ Respon akan muncul dari penerimaan pesan setelah terjadinya serangkaian komunikasi.

Respon pegawai akan dapat diketahui dengan mengukur tingkat kegunaan nilai relatif penting yang terdapat pada suatu produk pembiayaan. Bentuk fasilitas yang ditampilkan pada suatu produk pembiayaan dapat menimbulkan daya tarik pertama yang dapat mempengaruhi respon pegawai.Penilaian pegawai terhadap produk pembiayaan menggambarkan sikap pegawai terhadap produk pembiayaan tersebut, sekaligus dapat mencerminkan perilaku pegawai dalam menggunakan atau mengkonsumsi suatu produk pembiayaan.

Dari data yang diperoleh penulis melalui wawancara kepada pegawai IAIN Parepare dengan menjawab kuesioner dari responden.Ada beberapa hal yang perlu di analisis berdasarkan rumusan masalah, yakni bagaimana respon pegawai IAIN Parepare terhadap produk pembiayaan bank syariah?artinya responden diminta menjawab dan memberikan respon terhadap produk pembiayaan yang mereka gunakan dan memberikan alasan mengapa mereka memilih produk pembiayaan bank syariah tersebut.

Dalam hal ini hanya satu responden yang sesuai teori Parwadaminta yaitu dengan menanggapi serta memberikan reaksi dan jawaban mengenai respon terhadap pembiayaan pada bank syariah. ${ }^{30} \mathrm{Hal}$ ini diungkapkan sunandar:

“.... saya pernah menjadi salah satu nasabah pada bank syariah. Kenapa saya tahu karena pernah menawarkan kredit kepada pegawai dan dosen, dan saya menjadi salah satu nasabah yang mengambil kredit/pembiayaan disana dari banyaknya dosen dan pegawai.Kenapa saya waktu itu tertarik awalnya saya merasa terfasilitas dengan kemudahan prosesnya".

Responden penelitian ini adalah pegawai IAIN Parepare yang di ambil secara acak. Dari beberapa produk yang ada di bank syariah, ternyata produk simpanan yang banyak

\footnotetext{
${ }^{27}$ Muhammad Syafi'i Antonio, Bank Syariah Dari Teori Ke Praktik, h.98-99.

${ }^{28}$ Lihat Bab II Hal. 9

${ }^{29}$ Poerdawarminta, Psikologi Komunikasi, (Jakarta: UT, 1999), h. 43.

${ }^{30}$ Lihat Bab IV Hal. 37-38.
} 
diminati oleh pegawai IAIN Parepare yaitu produk Tabungan dengan akad mudharabah dengan sistem bagi hasil, sedangkan produk-produk lainnya seperti produk pembiayaan kurang mendapat perhatian dari pegawai IAIN Parepare hanya sebagian kecil pegawai yang memilih produk pembiayaan bank syariah.

Dari wawancara di atas, diketahui bahwa alasan yang membentuk respon terhadap yang menyebabkan pengetahuan dan sikap pegawai dalam memilih bank dilihat dari segi produk. Produk perbankan syariah belum memiliki nilai tambah dan keuntungan bagi penggunanya. Produk yang saat ini ditawarkan hampir sama bahkan sama dengan produk konvensional hanya kemasan dan namanya saja yang berbeda sehingga pegawai di IAIN Parepare belum sepenuhnya menggunakan produk perbankan syariah. Penggunaan produk perbankan syariah dilakukan apabila produk tersebut dapat memberikan keuntungan yang lebih dibandingkan produk perbankan konvensional.Untuk produk pembiayaan di bank syariah keuntungan yang diterima pegawai IAIN Parepare masih kalah apabila dibandingkan dengan produk bank konvensional, bahkan produk bank konvensional lebih variatif dan kompetitif sehingga pegawai IAIN Parepare memiliki alternatif dalam pemilihan produk tersebut.

Dari wawancara hasil penelitian, diketahui pula bahwa pegawai IAIN Parepare masih memiliki image mahal terhadap harga perbankan syariah khususnya produk pembiayaan, hal tersebut masih menjadi salah satu bahan pertimbangan pegawai dalam memilih perbankan serta diperoleh fakta bahwa image mahalnya produk pembiayaan di bank syariah umumnya diperoleh dari informasi teman atau relasi kantor, bisnis dan lain-lain. Selain itu juga, pada dasarnya perbankan syariah mendapat angin segar yaitu keunggulan di mana bank syariah memiliki sistem bagi hasil yaitu antara pihak pemodal dan yang menjalankan usaha sama-sama memberikan kontribusi dalam mendapatkan suatu keuntungan untuk memilih menggunakan jasa perbankan syariah.Tanggapan responden menunjukkan bahwa sebagian besar responden memberikan tanggapan positif.Kondisi ini memberikan kesan bahwa respon pegawai mengenai perbankan syariah dipersepsikan secara positif oleh responden. 


\section{Fadhliyah Ulfah Rustan, Sitti Jamilah, dan Syahriyah Semaun}

\section{Kesimpulan}

Berdasarkan penelitian yang telah dilakukan serta hasil yang diperoleh seperti yang telah dideskripsikan pada pembahasan sebelumnya, maka dapat ditarik kesimpulan bahwa :

1. Sistem pembiayaan pada produk bank syariah menggunakan empat pola atau sistem yang berbeda, yaitu :sistem bagi hasil, sistem jual beli,sistem sewa, sistem pinjaman.

2. Fasilitas yang diberikan oleh bank syariah berupa penyediaan dana untuk memenuhi kebutuhan pihak-pihak dengan sistem bagi hasil.

3. Tanggapan responden menunjukkan bahwa sebagian besar responden memberikan tanggapan positif. Kondisi ini memberikan kesan bahwa respon pegawai mengenai perbankan syariah dipersepsikan secara positif oleh responden.

Dari berbagai jenis produk yang ada di bank syariah hanya tabungan yang paling banyak diminati nasabah bank syariah serta alasan mereka memilih produk tersebut karena produk bank syariah sesuai syariah, halal dan aman. 


\section{Daftar Pustaka}

\section{Buku}

Ahmad, Mustaq. 2003. Etika Bisnis dalam Islam. Jakarta Timur: Pustaka Al-Kautsar.

Alwi, Hasan dkk. 2005. Kamus Besar Bahasa Indonesia: Departemen Pendidikan, edisi ketiga. Jakarta: Balai Pustaka.

Antonio, Muhammad Syafi'i. 1999. Bank syariab: bagi banker dan praktisi keuangan. Jakarta: Bank Indonesia Dan Tazkia Institute.

Antonio, Muhammad Syafi'i. 2001. Bank Syariah: Dari Teori Ke Praktik. Jakarta: Gema Insani Press.

Ascarya, 2006. Akad dan Produk Bank Syariab: Konsep dan Praktek di

Beberapa Negara. Jakarta: Bank Indonesia.

Chaplin, J. P. 2004. Kamus Lengkap Psikologi, cet. ke-9. Jakarta: PT. Raja Grafindo

Persada.

Dagun, Save D. 1997. Kamus Besar Ilmu Pengetahuan. Jakarta: Lembaga

pengkajian dan kebudayaan Nusantara.

Departemen Agama RI. 2006. Al-Qur'an dan Terjemahnya Juz 1-30 Edisi Baru. Surabaya: Pustaka Agung Harapan..

Echoles, John M dan Hassan Shadily.2003, Kamus Bahasa Inggris-Indonesia, cet.

Ke-27.Jakarta: PT. Gramedia.

Hasan, Zubair. 2009. Undang-Undang Tentang Perbankan Syariah. Jakarta: PT. RajaGrafindo Persada.

Ismail. 2011. Perbankan Syariah. Jakarta: Kencana Prenadamedia Group.

Karim, Adiwarman A. 2008. Bank Islam: Analisis Fiqih Dan Keuangan.Jakarta: PT. RajaGrafindo Persada.

Muhammad. 2015. Manajemen Dana Bank Syariah. Jakarta: RajaGrafindo Persada.

Poerdawinata. 1999. Psikologi Komunikasi. Jakarta: UT

Rahmat, Jalaludin. 1999. Psikologi Komunikasi. Bandung: Remaja Rosdakarya.

Sekolah Tinggi Agama Islam Negeri. 2013. Pedoman Penulisan Karya Ilmiah (Makalab Dan Skripsi). Parepare: IAIN.

Subandi, Ahmad. 1982. Psikologi Sosial.Jakarta: Bulan Bintang. 


\section{Fadhliyah Ulfah Rustan, Sitti Jamilah, dan Syahriyah Semaun}

Susanto. 1997. Dasar-dasar Manajemen. Edisi Baru. Jakarta: Miswa.

Tim Prima Pena. 2006. Kamus Lengkap Bahasa Indonesia. Jakarta: Gitamedia Press.

Walsito, Bimo. 1999. Psikologi Umum. Yogyakarta: UGM.

\section{Jurnal}

Annisa Prasetyanti, Pelaksanaan dan Sistem Bagi Hasil Pembiayaan Al-Mudharabah Pada Bank Syariah. Universitas Merdeka Malang https://media.neliti.com.

E Yonaria, Teori Pegawai Bab 2 Landasan Teori repository.unair.ac.id

E Kurniawati.Bab II Teori Respon. digilib.iainkendariac.id.

Himpunan Fatwa Majelis Ulama Indonesia, mui.orid/Bunga-InterestFaidah.pdf.

Mirawati, Pembiayaan Murababah: Analisis Persepsi Nasabab Bank. Muamalat

Indonesia Cabang Pekabaru.Joernal.umsb.ac.id//213/175

Munawarotul Kiptiah, Respon kognitif, efektif dan konatif pegawai http://repository.unair.ac.id

Muttaqim Nurhuda, Analisis Pelaksanaan Akad Pembiayaan Murababah di BMT Palur Karanganyar. http://eprints.ums.ac.id.Universitas Muhammadiyah Surakarta.

OF Asmono.Bab II Landasan Teori Pegawai. eprints.ums.ac.id/pdf.

\section{Website}

Bcasyariah.co.id

Bankmuamalat.co.id

Syariahmandiri.co.id 